KINGA KUSZAK

Uniwersytet im. Adama Mickiewicza

w Poznaniu

\title{
DZIECKO W PRZESTRZENIACH JĘZYKA OJCZYSTEGO - WYBRANE ASPEKTY
}

ABSTRACT. Kuszak Kinga, Dziecko w przestrzeniach jezyka ojczystego - wybrane aspekty [Children in the Space of their Native Language - Selected Aspects]. Studia Edukacyjne nr 42, 2016, Poznań 2016, pp. 65-83. Adam Mickiewicz University Press. ISSN 1233-6688. DOI: 10.14746/se.2016.42.4

The article discusses various spaces of children's linguistic functioning and the wealth of linguistic experiences available in each of them. The author points to the fact that each of these spaces provides children with different vital experiences. The starting point for the reflections on the spaces of native language is Ferdinand de Saussure's concept of speech as a human ability and language as a set of forms of speech uses. The term "linguistic space" and the criteria for determining a space were adopted from the works of Kwiryna Handke who emphasized that language, as an integral structural component of social space and the community that uses it, plays two roles in this space: it reflects the community's perception of its surroundings and provides help and basic tool for shaping the space. Therefore, the forms of language use differ according to the spaces, situations and roles which one encounters. The next part of the paper presents selected vocabulary that children may potentially acquire in the following spaces: family, kindergarten (school), peer group, via Internet communication, as viewers of TV commercials and readers (recipients) of literature. The summary presents the spaces of children's linguistic functioning in the form of a chart, taking into account the roles adopted by children in each space, places and situations distinctive of the space, as well as the words, expressions, and language tools typical for each space.

Key words: child, native language, language acquisition, child's linguistic experiences, vocabulary expansion

\section{Wprowadzenie}

Zdaniem Ferdinanda de Saussure'a, mowa (langage) jest pewnym zjawiskiem, zdolnością, którą został obdarzony człowiek, zaś język (langue) to zbiór form, jakie to zjawisko przejmuje $\mathrm{w}$ określonym czasie historycznym 
(epoce) „od pewnej zbiorowości indywiduów”1. Mowa i język wzajemnie na siebie oddziałują. Ponadto, „w trakcie mowy język znajduje swe zastosowanie, a jednocześnie swe jedyne i ciągłe źródło”, zaś mowa jest „zarówno wdrożeniem, jak i nieustannym generowaniem języka" 2 , jego odtwarzaniem i tworzeniem.

Język jest systemem znaków, z których każdy składa się z dwóch elementów: sygnału (element znaczący) i jego znaczenia (element oznaczany). Jak podkreśla Ferdinand de Saussure, „istnienie, które można przypisać znakowi, polega zasadniczo jedynie na dokonywaniu w umyśle jego skojarzenia z pojęciem" ${ }^{\prime 3}$. Znak jest arbitralny, istnieje w umyśle osób posługujących się nim dla oznaczenia zjawisk i rzeczy. Nie ma jednak powodu, który usprawiedliwiłby przyporządkowanie określonego znaku do danego znaczenia. Dlatego, właśnie w różnych językach znaczenia kodowane są za pomocą odmiennych sygnałów. Znaczenie "kon" związane jest w języku polskim z formą dźwiękową „kon", w języku francuskim "cheval”, w angielskim „horse”, w niemieckim „Pferd, we włoskim „cavallo"4. Rzeczywisty obiekt w przestrzeni charakteryzowany jest przez dwa elementy znaku - signifiant (składnik akustyczny, pisany, wizualny itp.) i signife - przedstawienie mentalne tego obiektu. Signifiant jest inny w zależności od języka, którym posługują się jego użytkownicy. Pojawia się on w sytuacji mówienia (pisania), czyli w relacji z innymi ludźmi, co podkreśla F. de Saussure następującymi słowami:

indywiduum przygotowane do tego, by mówić, może zacząć korzystać ze swojego aparatu mownego tylko za sprawą wspólnoty, do której należy; co więcej tylko w relacjach z nią właśnie doświadcza ono potrzeby używania tego aparatu5.

Wspomniany autor podkreśla rolę społecznego charakteru języka i mowy, zwraca uwagę, że mowa, podobnie jako „obyczaje”, jest właściwością wspólnoty, w której funkcjonuje jednostka. Wspólnota jest „zbiorem podmiotów, które rozumieją ten sam język"6. Może zostać wyznaczona granicami geograficznymi (region, dzielnica), politycznymi (narodowość), społecznymi (grupa zawodowa, rodzina), etnicznymi itp.

Zdaniem Kwiryny Handke, język jako integralny komponent strukturalny przestrzeni społecznej i posługującej się nim wspólnoty odgrywa w tej

\footnotetext{
1 F. De Saussure, Szkice z językoznazwstwa ogólnego, Warszawa 2002, s. 131.

2 Tamże.

3 Tamże, s. 67.

${ }^{4}$ Ch. Baylon, X. Mignot, Komunikacja, Kraków 2008, s. 24.

${ }^{5}$ F. De Saussure, Szkice z językoznawstwa ogólnego, s. 171.

${ }^{6}$ B. Ollivier, Nauki o komunikacji, Warszawa 2010, s. 31.
} 
przestrzeni dwojaką rolę: odzwierciedla sposób widzenia otaczającego świata przez społeczność danego miejsca, stanowi pomoc i główne narzędzie $\mathrm{w}$ kreowaniu tej przestrzeni 7 . Przestrzeń języka wyznaczona jest przez:

- miejsce (terytorium),

- cechy i specyfikę grupy społecznej,

- role pełnione przez poszczególnych członków grupy i relacje między nimi (symetryczne vs. niesymetryczne),

- narzędzia - środki językowe charakterystyczne dla tego miejsca i specyfiki grupy 8 .

W literaturze psychologicznej wyróżnia się kilka typów przestrzeni: publiczną, społeczną, prywatną, osobistą (intymną). W każdej z nich obowiązuje inny język.

Przyjmując powyższe kryteria, podejmę próbę przyjrzenia się specyfice języka charakterystycznego dla danej przestrzeni społecznej i danej wspólnoty funkcjonującej $\mathrm{w}$ tej przestrzeni. Moim zamierzeniem jest zwrócenie uwagi, iż stanowiąc część wspólnoty i funkcjonując w odpowiadających danej wspólnocie miejscach, dziecko opanowuje język charakterystyczny dla tej grupy i przestrzeni. Poznaje i bogaci słownictwo dzięki bezpośrednim relacjom $\mathrm{z}$ innymi ludźmi $\mathrm{w}$ domu rodzinnym, przedszkolu, szkole, ale również za pośrednictwem mediów i dzięki możliwości obcowania z literaturą. W każdej z tych przestrzeni zdobywa doświadczenia językowe ważne dla dalszego funkcjonowania, uczy się używać mowy w różnych kontekstach (kontekście semantycznym (lingwistycznym), interpersonalnym, instrumentalnym (zadaniowym) i kulturowym ${ }^{9}$ ). Trzeba jednak zaznaczyć, że pewne słowa, sformułowania, określenia są charakterystyczne wyłącznie dla danej przestrzeni; w innych przestrzeniach nie występują, nie są używane przez inne wspólnoty. Dziecko może więc poznać pewne słowa, określenia, związki wyrazowe tylko dzięki możliwości obcowania z innymi ludźmi $\mathrm{w}$ danej przestrzeni. Im więcej różnych przestrzeni poznaje, tym szansa na zdobycie bardziej zróżnicowanych i bogatych doświadczeń językowych jednostki. Warto nadmienić, że funkcjonując w różnych przestrzeniach jednostka może poznawać i przyswajać podobne/zbliżone słowa. Zarówno w domu rodzinnym, jak i przedszkolu (szkole) ma okazję poznać określenia służące np. wyrażaniu grzeczności, kierowaniu zachowaniem innych ludzi, wyrażaniu emocji itp. W środowisku rodzinnym i rówieśniczym poznaje elementy języka potocznego, kolokwializmy, elementy żargonu, ale także słownictwo specjalistyczne. $Z$ wyszukanymi środkami językowymi ma moż-

\footnotetext{
7 K. Handke, Socjologia jezzyka, Warszawa 2009, s. 48.

8 Tamże.

${ }_{9}^{9}$ Z. Nęcki, Komunikacja międzyludzka, Kraków 2000, s. 92 i n.
} 
liwość spotkać się podczas kontaktów z literaturą na terenie domu rodzinnego, przedszkola, szkoły, biblioteki itp.

$\mathrm{W}$ dalszych rozważaniach zwrócę uwagę na wybrane przestrzenie, w których funkcjonuje współczesne dziecko zdobywając ważne doświadczenia dla swojego rozwoju językowego. Przykłady słów, zwrotów, które przytoczę nie wyczerpują całego zasobu słownictwa, jakie poznaje jednostka w wymienionych przestrzeniach. Nie sposób bowiem przywołać całe bogactwo, jakie dziecko potencjalnie ma możliwość przyswoić, dlatego poprzestanę na pewnym ograniczonym wyborze.

\section{Przestrzeń języka familijnego}

Język familijny (rodzinny, domowy) jest pierwszym językiem, jaki dziecko poznaje $\mathrm{w}$ najbliższej mu przestrzeni domu rodzinnego, dzięki relacjom komunikacyjnym z rodzicami, rodzeństwem, dziadkami, dalszą rodziną. Jest odmianą nieoficjalną języka zawierającą elementy kolokwialne, żargonowe, dialektalne, regionalne, a także ekspresywizmy i neologizmy ${ }^{10}$. Zdaniem K. Handke, do lingwistycznego zakresu języka familijnego należą: repertuar faktów i zjawisk językowych oraz zjawiska ilustrujące zachowania językowe typowe dla poszczególnych członków rodziny ${ }^{11}$. W niniejszym opracowaniu skoncentruję swoją uwagę właśnie na tym aspekcie języka familijnego. Repertuar faktów i zjawisk językowych, którym jednostka posługuje się $\mathrm{w}$ kontaktach $\mathrm{z}$ najbliższymi tworzą:

- miejsce, w którym spędza się czas w ciągu dnia (gabinet - pokój służący do pracy);

- mazwy członków rodziny i grupy domowej, nazwy stopni pokrewieństwa i powinowactwa (np. wuj, stryj, kuzyn, przyszywany brat, taka jakby ciocia, praciocia, bunia, dziadziu);

- formy adresatywne i epitety (np. "kochanie, prosze cię", „skarbie, czy możesz mi pomóc", "rybeczko, spójrz" itp.);

- nieoficjalne formy imion, nazwisk i przezwisk, zgrubienia (np. dziewuchy, dzieciska, chłopczysko itp.), zdrobnienia (np. imion: Madzia, Miet, Błażuś, Alisi);

- zdrobnienia służące codziennej komunikacji (np. zjedz prędziudko, umyj szybciutko rączki, pokaż buziulkę, tuptaj do tóżeczka, zjedz chlebek z masetkiem i miodzikiem);

${ }^{10}$ K. Handke, Socjologia języka, s. 76-77.

${ }^{11}$ Podział za: tamże, s. 78, przykłady własne. 
- formy pieszczotliwe (dziubeczku, miśku, córciu);

- wyrazy i zwroty ekspresywne (skarbusiu mój kochany, myszeńko, jak pięknie!, cudownie, brawo!).

Należy podkreślić, że $\mathrm{w}$ relacjach $\mathrm{z}$ najbliższymi ważną rolę odgrywa funkcja ekspresywna języka. Ekspresja wokalna towarzysząca wypowiadanym słowom pozwala rodzicom na przekazywanie emocji i wczesną edukację językową, zwaną „kąpielą słowną”, w okresie kiedy dziecko nie rozumie jeszcze znaczenia kierowanych w jego stronę słów. Szczególną rolę odgrywa wówczas "przerysowana” intonacja, zmiany tempa mówienia, wzmacnianie i ściszanie głosu12. S. Milewski podkreśla ponadto, że dorośli za pomocą akcentów i intonacji zaznaczają niektóre słowa kierowane w stronę dziecka, a budowane przez nich zdania mają wyrazistą strukturę ${ }^{13}$.

Z kolei, zjawiska ilustrujące zachowania językowe typowe dla poszczególnych członków rodziny ze względu na ich pozycję w grupie, odzwierciedlające relacje między członkami rodziny to wypowiedzi typu: mój ty największy skarbie, kotuś, martwię się o ciebie, misiu, stuchaj mamusi, słoneczko moje, pomóż babuni itp. Cechą charakterystyczną tych zjawisk językowych jest łączenie elementów werbalnych i niewerbalnych w całość aktu komunikacyjnego. Tym, co odznacza język w przestrzeni rodzinnej jest wyrażanie za jego pośrednictwem miłości, czułości, troski. Język bogaty jest więc w określenia i zwroty pozwalające na wyrażanie emocji pozytywnych. Charakteryzują go określenia infantylne, np. lulaj, płakusiać, utulać itp., specyficzne formy derywantów hipokrostycznych, $\mathrm{w}$ tym wieloprzyrostkowe przymiotniki, np. maluteńka, słodziunieczka, szybciusieńko, pomaluteńku itp., elementy dźwiękonaśladowcze, np. gili-gili, szuru-buru, pam-pam, dylu-dylu, ćwir-ćwir itp., formy stopnia najwyższego przymiotników, np. najukochańszy, najmądrzejszy, najwspanialszy, najgrzeczniejszy itp. Język domowy wykorzystuje neologizmy tworzone przez członków rodziny na potrzeby różnych sytuacji, w których uczestniczą np. chorutek, madraszek, odważniak, spryciurek itp. W trakcie relacji wewnątrzrodzinnych dziecko poznaje język empatii i uczy się zachowań empatycznych. Badania wskazują, że dzieci o bliskich, czułych więziach emocjonalnych, doświadczające werbalnej komunikacji wyrażającej emocje, lepiej radzą sobie z rozumieniem uczuć innych osób i troskliwym odnoszeniem się do nich:

- codziennych relacji komunikacyjnych, np. chce ukochać, a nie będziesz ptakała?

12 S. Milewski, Mowa dorostych kierowana do dzieci, Gdańsk 2011, s. 30.

13 Tamże, s. 29. 
- w sytuacji zabawy i wchodzenia w rolę innej postaci: „(...) uśmiechaj się do mnie, pokochaj mnie tloske, moja kochana (...) O! kochana pupunia, zlobita sisisu do nocnika, a telaz śpij, a ja idę do sklepu pa, pa (...) Choć apka hopsia, hopsia, moja kochana lalunia"14.

Z. Dysarz podkreśla, że efektywność uczenia się przez dziecko zachowań językowych związana jest $\mathrm{z}$

doznawaniem przez nie satysfakcji emocjonalnej i poznawczej w interakcji społecznej. Badania poziomu rozwoju mowy u dzieci doświadczających deprywacji emocjonalnej ze strony rodziny wykazały bardzo niski poziom opanowania kompetencji językowej i komunikacyjnej ${ }^{15}$.

\section{Przestrzeń języka (przed)szkolnego}

Wkraczając w przestrzeń najpierw przedszkola, później szkoły dziecko poznaje cechy języka formalnego, na który składają się:

- Rutynowe czynności językowe, które wynikają z powtarzalnych i przewidywalnych działań podejmowanych podczas zajęć (lekcji) przez nauczyciela i dzieci (uczniów), do których można zaliczyć: rozpoczynanie lekcji, sprawdzanie obecności, podczas którego oczekuje się od dzieci określonego zachowania językowego typu: jestem, obecny, nieobecny itp., usprawiedliwianie (np. nieobecności, nieprzygotowania, braku materiałów potrzebnych do zajęć), zgłaszania potrzeb (np. wyjścia do toalety), przebiegiem lekcji (np. Przystapimy obecnie do następnej części naszych zajęć, Czy ktoś chciałby sie jeszcze wypowiedzieć na ten temat?, Jak ktoś zrobit, to siedzi prosto i czeka) ${ }^{16}$, zakończenia lekcji (np. zadanie dokończycie $w$ domu, $w$ domu przeczytajcie to opowiadanie, do zobaczenia, do jutra, na jutro nie zapomnijcie przynieść itp.).

- Grzeczność wyrażona w języku, którą rozumiem jako „używanie przez mówiącego określonych wyrażeń językowych w funkcji grzecznościowej"17, które nie podlegają weryfikacji ze względu na szczerość mówiącego. Specyfiką grzeczności na terenie szkoły jest jej asymetria polegająca na tym, że nauczyciel zwraca się do dziecka po imieniu, zaś dziecko do nauczyciela mówi: prosze pani, proszę pana ${ }^{18}$. Od dziecka (ucznia) oczekuje się stosowania

${ }^{14}$ H. Zgółkowa, Świat w dziecięcych słowach, Poznań 1990, s. 78-79.

15 Z. Dysarz, Mowa dziecka a więzi uczuciowe w rodzinie, Bydgoszcz 2003, s. 167.

${ }^{16}$ M. Nowicka, Przestrzeń fizyczna klasy szkolnej jako środowisko socjalizacji dziecka, [w:] Problemy wczesnej edukacji. Problemy, dyskursy, otwarcia, red. D. Klus-Stańska, D. Bronk, A. Malenda, Warszawa 2011, s. 264-266.

${ }_{17}$ M. Marcjanik, Grzeczność w komunikacji językowej, Warszawa 2013, s. 13.

${ }^{18} \mathrm{~W}$ przedszkolu do nauczycielki zwraca się ciociu. 
określonych form komunikatów w sytuacji przywitania, pożegnania, zwracania się do nauczyciela z prośbą, podziękowania, przeprosin. Wyrazem grzeczności jest słuchanie i milczenie, co wyrażają następujące wypowiedzi dzieci: jak pani mówi, to nie wolno przerywać, generalnie lepiej nie mówić, bo można dostać uwagę, będzie kara, więc nic nie mówię, nie mogę powiedzieć, ponieważ pani zabrania ${ }^{19}$. Grzeczność językowa eksponowana jest także w relacjach z rówieśnikami, dzieci nakłaniane są do formułowania stosownych zwrotów wobec rówieśników: przeproś Jasia, podziękuj Marysi, pożegnaj się ładnie z dziećmi, Stasiu, powiedz dzień dobry. Grzeczność werbalna i niewerbalna (milczenie, spokojne siedzenie) jest nagradzana, np. Wybieram tylko ładnie zgłaszające się dzieci. Musisz poczekać, siadaj prosto i nie przeszkadzaj. Patryk, nie krzycz, mów spokojnie o co ci chodzi20.

- Komunikaty dyrektywne i sterujące zarezerwowane są dla nauczyciela. Ma on przywilej formułowania takich komunikatów, jak: podejdź do tablicy, zapisz to inaczej, pisz wyraźnie, popraw tutaj, przeczytaj jeszcze raz, I teraz zapisujemy punkty do zeszytu ładnie i starannie ${ }^{21}$, przepiszcie rozwiązanie z tablicy, a odpowiedź ułóżcie sami22. M. Nowicka opisując specyfikę relacji między uczestnikami procesu komunikacji w klasie szkolnej, stworzyła listę następujących komunikatów dyrektywnych kierowanych przez nauczyciela w stronę uczniów. Zaliczyła do nich: kierowanie - drobiazgowe instruowanie, oświecanie - narzucanie sposobów myślenia i percepcji rzeczywistości, ugrzecznianie - stałe dyscyplinowanie, legitymizowanie autorytetu z nadania - kult osoby nauczyciela, dystansowanie - formalizowanie stosunków, oswajanie - maskowanie i wzmacnianie władzy klimatem życzliwości, uzależnianie - wzmacnianie przywiązania dziecka do autorytetu, uwstecznianie - ograniczanie samodzielności ${ }^{23}$.

- Dominuje słownictwo specjalistyczne, które już w przedszkolu dotyczy różnych obszarów nauki, życia zawodowego, sztuki, historii24, czego przykładem mogą być następujące wypowiedzi dzieci: „pojechaliśmy w poniedziałek do Aklykaium do Zoo yy, tak się nazywało i najciekawse było, jak ryby pływały

${ }^{19}$ K. Kuszak, Kompetencje komunikacyjne dzieci w okresie późnego dzieciństwa w aspekcie rozwojowym, Poznań 2011, s. 313.

20 Przykłady za M. Nowicka, Przestrzeń fizyczna klasy szkolnej jako środowisko socjalizacji dziecka, [w:] Problemy wczesnej edukacji, s. 248-269.

21 Tamże, s. 254.

22 Tamże.

23 M. Nowicka, Socjalizacja na lekcjach w klasach początkowych. Praktyki-przestrzeniekonceptualizacje, Torun 2010, s. 164.

24 Do tej grupy słów można też zaliczyć słownictwo dotyczące Internetu. Biorąc pod uwagę fakt, że rzeczywistość wirtualna jest dla dziecka przestrzenią odrębną, również słownictwo $\mathrm{z}$ tego obszaru zostało przeze mnie omówione oddzielnie. 
wsędzie” (ch. 4 lata), „Dzień dobry... Prosze o wyłaczenie komórków... i prosze o zachowanie ciszy i proszę nie biegać po... po kukiełkach. Okej? Bo kukietki sa waż$n e "$ (dz. 3,5 roku), "A tą kapsuta nie mogą odlecieć i latać $w$ kosmosie, bo ona jest za wielka..." (ch. 6 lat), "Ona będzie zdrowa. Trzeba receptę $i$ do domu. Nie może chodzić do przedszkola" (dz. 3 lata). Badania prowadzone przez A. Balawender wskazują, że zaplanowane i celowe działania edukacyjne prowadzone na terenie przedszkola sprzyjają poszerzaniu zasobu słownictwa specjalistycznego u dzieci w wieku 4-6 lat. Pracując metodą projektów koncentrujących się wokół tematyki zawodu lekarza (projekt: „Lekarz”), autorka dostrzegła wzbogacenie zasobu słownikowego dzieci o następujące słowa: okulista, chirurg, okulary korekcyjne, soczewka, rogówka, źrenica, tęczówka, twardówka, oczodoty, stetoskop, wziernik, stomatolog, zdjęcie rentgenowskie, prześwietlenie, kość strzatkowa, kość udowa, kość piszczelowa, kość ogonowa, biodro, żebra, czaszka, płuca, serce, nerki, nerwy, mózg, żyły, mikroskop 25 . W okresie szkolnym słownictwo specjalistyczne rozszerza się i wzbogaca. Zdaniem J. Malendowicz, największy przyrost liczebności słów przypada na klasę drugą i trzecią²6. W tym okresie bogacące się słownictwo obejmuje m.in. słowa dotyczące przedmiotów szkolnych, pomieszczeń szkolnych, zajęć pozalekcyjnych, uroczystości szkolnych, osób znajdujących się w szkole ${ }^{27}$. Oczywiście, nie można zapomnieć, że słownictwo specjalistyczne rozwija dziecko także dzięki zainteresowaniom stymulowanym w najbliższym otoczeniu, przez rodziców i dziadków 28 .

\section{Przestrzeń języka grupy rówieśniczej}

Dziecko poznaje język grupy rówieśniczej podczas relacji komunikacyjnych z innymi dziećmi: kolegami starszym rodzeństwem, kuzynostwem itp. Dzieje się to zarówno w przedszkolu, szkole, podczas nieformalnych relacji z kolegami i koleżankami, ale także podczas spotkań i zabaw pozalekcyjnych, na podwórku, w sąsiedztwie, a także kontaktując się z rówieśnikami

${ }^{25}$ A. Balawender - niepublikowana praca magisterska: Metoda projektów jako innowacyjna metoda zdobywania doświadczeń przez dzieci w wieku przedszkolnym, przygotowana pod kierunkiem K. Kuszak, UAM, 2016 r.

${ }_{26}$ Podaję za D. Czelakowska, Metodyka edukacji polonistycznej dzieci w wieku wczesnoszkolnym, Kraków 2014, s. 130.

${ }^{27}$ K. Kuszak, Kompetencje językowe uczniów klas młodszych szkoty podstawowej, [w:] Dziecko w szkolnej rzeczywistości. Założony a rzeczywisty obraz edukacji elementarnej, red. H. Sowińska, Poznań 2011, s. 179.

${ }^{28} \mathrm{Na}$ ten temat szerzej: K. Kuszak, Stownictwo specjalistyczne uczniów w młodszym wieku szkolnym. Zainteresowania i doświadczenia utrwalone w jezzyku, Studia Edukacyjne, 2015, 36, s. 219-233. 
za pośrednictwem mediów (telefonu, Internetu ${ }^{29}$ ). Do cech tej odmiany języka zalicza się:

- Wypowiedzi krótkie i ubogie w środki językowe, styl esemesowy wypowiedzi, koncentracja na syntetycznej treści, bez dbałości o formę przekazu, co konkluduje Halina Zgółkowa w następujący sposób „absolutnie powszechne jest skracanie właściwie wszystkiego, co da się zapisać skrótowcami np. esy - SMS-y, BTW - by the way (przy okazji), OMG - o, My God (mój Boże)" $"$.

- Nadmiar słów wytrychów typu: fajnie, nie fajnie, super, ekstra, spoko, okej, używanych w różnych sytuacjach, kategoriach znaczeniowych, bez konieczności zwracania uwagi na precyzję i staranność budowania wypowiedzi. Włodzimierz Goriszowski w odniesieniu do wyrażenia okej zaznacza, że młode pokolenie posługuje się nim do oznaczenia samopoczucia, oceny kolegi (koleżanki), czy sytuacji życiowej31.

- Wypieranie polskich określeń słowami pochodzącymi z języka angielskiego i zamiast: znakomity, doskonaty - cool, ekstra; thank; zamiast: dziękuje nice (polska wersja: zapisu najs); zamiast: dobrze, sympatycznie, miło - high five (polska wersja zapisu: haj fajf), czyli: cześć lub przybij piątkę; hejtować (od angielskiego: hate), czyli krytykować, negatywnie oceniać. Do tej listy Jan Miodek dodaje jeszcze: lol, banglać, banus, flow, herka, plonk, wtopa, zmulant32, a Włodzimierz Goriszowski: kminić, kit33.

- Wypełnianie wolnej przestrzeni w języku przez określenia mające swoje źródło w języku angielskim dotyczy pojawiających się na rynku zabawek o angielskich, czasem spolszczonych nazwach, np. samochody hotwheels nazywane są przez uczniów hottilkami, a zabawka o nazwie transformers w liczbie mnogiej to transformersy. Wiele modnych wśród najmłodszego pokolenia zabawek i przedmiotów nie ma polskich odpowiedników, stąd w języku uczniów funkcjonują wyłącznie nazwy angielskie, takie jak: Spiderman, Power Rangers, Hello Kity, czy Ben Ten. Nawiązania do angielszczyzny można odnaleźć także w takich formach, jak: debeściak, debeściarski, krejzol, lajtowy, lajcik, lukać34. Słowem, które weszło na stałe do słownika młodego, ale i starszego pokolenia jest słowo finisz, które, jak odnotowuje

${ }^{29} \mathrm{Na}$ ten temat szerzej w dalszej części opracowania.

${ }^{30} \mathrm{H}$. Zgółkowa, Gwara uczniowska (szkolna) w poszukiwaniu inspiracji, [w:] Oblicza polszczy$z n y$, red. A. Markowski, R. Pawelec, Warszawa 2012, s. 87.

31 W. Goriszowski, Kształtowanie kultury języka ojczystego w społeczeństwie ważnym problemem pedagogicznym, [w:] Jezyk - Literatura - Wychowanie, red. J. Bałachowicz, S. Frycie, Warszawa 2006, s. 142.

32 J. Miodek, Polszczyzna różnych pokoleń, [w:] Oblicza polszczyzny, s. 49.

${ }^{33}$ W. Goriszowski, Ksztattowanie kultury jezyka ojczystego, s. 142.

34 Tamże, s. 50. 
Katarzyna Dróżdż-Łuszczyk, obecnie otrzymuje nową formę finisaż, czyli uroczyste zamknięcie czegós 35 .

- Skracanie wyrazów i całych zwrotów, np. nara zamiast na razie; dozo zamiast do zobaczenia; spok, spoksik zamiast spokojnie; siema, siemka zamiast jak sie masz; elo zamiast dzień dobry, cześć; bojo zamiast boisko. Jan Miodek do tej listy dodaje: $w$ porzo, czyli w porządku; cze - co oznacza cześć; impra zamiast impreza; spontan, zamiast coś spontanicznego; fryz zamiast fryzura36.

- Stosowanie wyzwisk i przezwisk. Te pierwsze mają zazwyczaj charakter obraźliwy, wulgarny, reprezentują pospolitą odmianę języka, zaś przezwiska inspirowane są zazwyczaj cechą, cechami wyglądu, odnoszą się do umiejętności, wiedzy, zainteresowań, są rezultatem twórczego przekształcenia nazwiska lub imienia. $\mathrm{W}$ przypadku nauczycieli uczących $\mathrm{w}$ klasach starszych są rezultatem skojarzenia z prowadzonym przez nich przedmiotem.

- Wulgaryzmy i określenia obraźliwe typu: jesteś głupi, bo cię walnę, nie wystawiaj języka bo ci krowa nasika. Stosowane są przez uczniów w sposób całkowicie świadomy, w celu poniżenia, obrażenia, skrzywdzenia rozmówcy ${ }^{37}$.

\section{Przestrzeń języka reklamy}

Charakteryzując język reklamy, zwraca się uwagę, iż dominuje w nim funkcja perswazyjna, a komunikat zbudowany z mikroaktów (pośrednich bądź bezpośrednich): zachęty, nakłaniania, stwierdzania, chwalenia, proponowania, rady, gwarancji, obietnicy ${ }^{38}$ (przy czym, jeden mikroakt często pełni więcej niż jedną funkcję pragmatyczną). Perswazyjny makroakt reklamowy składający się z mikroaktów łączy na pozór wykluczające się, różne czynniki: racjonalizm i irracjonalizm, rozsądek i emocje, naukowości i myślenie magiczne.

Te odmienne sposoby poznawania wzajemnie się przenikają, pomagając $\mathrm{w}$ deszyfryzacji intencji nadawcy; zarówno tych obecnych w strukturze powierzchniowej, jak i ukrytych w strukturze głębokiej aktu reklamowego ${ }^{39}$.

${ }^{35}$ K. Dróżdż-Łuszczyk, O nowej formie finisaż w systemie leksykalnym polszczyzny, [w:] Język i logopedia, red. Z. Zaron, J. Porayski-Pomsta, Warszawa 2013, s. 23- 32.

36 Tamże, s. 49.

37 Więcej na ten temat K. Kuszak, Edukacja językowa jako element edukacji kulturowej uczniów, [w:] Kultura - Sztuka - Edukacja, t. I, red. B. Kurowska, K. Łapot-Dzierwa, Kraków 2015, s. 310-319.

38 J. Lizak, Jezzyk reklam dla dzieci, Rzeszów 2006, s. 109.

${ }^{39}$ Tamże, s. 110. 
Środki stylistyczno-językowe reklamy oddziałujące na cechy języka młodego pokolenia to ${ }^{40}$ :

- rym (np. zabawa tkwi w Toffifee, Petitki Lubisie, to przepyszne misie);

- aliteracja (np. Bum, bum, Boomer, To llubię Gellwe);

- figury słowno-dźwiękowe (wydłużenie samogłosek, dźwiękowa ekspresja artykulacyjna, np. strrrasznie fajnie, coś naprrrawde ekstra, ekstrrremalna szybkośc);

- akcent retoryczny - akcentowe uwydatnienie początku wyrazu, zaznaczone krótką pauzą (np. po-żywne, py-szne);

- słownictwo magiczne - sprawia, że przedmiot reklamy staje się zgodny z wyobrażeniami dziecka. Pozwala ono reklamodawcy wejść w bliski związek z dziecięcym odbiorcą (np. czary $z$ mleka ${ }^{41}$, to będzie dzień peten niespodzianek, niespodzianki sa tak kochane ${ }^{42}$ );

- modne wyrazy (np. maximum smaku, przyjemność na maksa, mega promocje, mega przyjemność itp.);

- anglicyzmy (np. the freshmaker ${ }^{43}$, go ahead, perfectly you ${ }^{44}$, wash and go);

- leksemy nacechowane potocznie (np. Jestem gepard Chester, na luzie ze mnie gość!);

- neologizmy (np. smoczny sok, ekopaczka, "mój superowy przepis na rozweselanie mamy. Delects prosto $z$ serca");

- frazeologizmy (np. z Kasia ci się upiecze, czekoladowe MEM'sy leca w kulki) i przysłowia (np. Fortuna sie kołem nie toczy, Fortuna się toczy owocem, nie ma jak u Malmy);

- kwantyfikatory (typu: wyjątkowy, jedyny, specjalny, wyjątkowy, szczególny, tylko, jedynie, wyłacznie 45 , warto - warto mieć własne zdanie, ale też: prawdziwy - prawdziwa kawa, prawdziwie czyste zęby ${ }^{46}$, ale także: bielszy odcień bieli).

Język reklamy to język emocji, odzwierciedlający dynamikę ruchu, to język agresywny, perswazyjno-nakazowy ${ }^{47}$, co odzwierciedla następujący przykład: „Hot Whells City, przygotuj się na starcie z rekinem! O! Tym razem cię

40 Podaję za: tamże, s. 136-159.

${ }^{41}$ Reklama batona Milky Way.

42 Reklama Kinder Niespodzianki.

${ }^{43}$ Reklama dropsów Mentos, podaję za M. Spychalska, M. Hołota, Stownik sloganów reklamowych, Warszawa, 2009, s. 172/

${ }^{44}$ Podaję za: J. Bralczyk, Język na sprzedaż, czyli o tym, jak język stuży reklamie i jak reklama używa języka, Gdańsk 2004, s. 55.

45 J. Lizak, Jezyk reklam dla dzieci, s. 159.

${ }^{46}$ Za: J. Bralczyk, Jezzyk na sprzedaż, s. 61.

$47 \mathrm{Na}$ ten temat więcej w: K. Kuszak, Werbalne kompetencje w spoteczeństwie wiedzy, [w:] Kompetencje kluczowe dzieci i młodzieży. Praktyka edukacyjna, red. J. Uszyńska-Jarmoc, K. Nadachewicz, Warszawa 2015, s. 45-63. 
dopadt! Zanurz samochodzik w wodzie! Brawo! Nowy kolor to nowa szansa! Potwór pokonany! Rozbuduj świat Hot Wheels. Starcie z rekinem to poczatek przygody!".

\section{Przestrzeń języka Internetu}

Współczesne dziecko równocześnie z nauką mówienia i chodzenia w świecie realnym, uczy się poruszania i komunikowania w świecie wirtualnym. Dzięki funkcjonowaniu w przestrzeni mediów, poznaje możliwości komunikacji niebezpośredniej $\mathrm{z}$ innymi ludźmi. Codzienne obserwacje pozwalają zauważyć, że już dzieci w wieku przedszkolnym szybko i z łatwością odnajdują się w rzeczywistości wirtualnej. Najmłodsze pokolenie określa się mianem "pokolenia Internetu”, „pokolenia Fecebooka”, „egeneracja". Poruszając się w przestrzeni wirtualnej, dzieci szybko opanowują funkcjonujące w niej słownictwo, które odnosi się do:

- adresów elektronicznych; jak podkreśla Jan Grzenia,

ich odczytywanie i tworzenie wymaga znajomości kodu, ten jednak jest w ogólnym zarysie czytelny, oparty na prostej zasadzie łączenia składników, którymi są elementy znane lub łatwo rozpoznawalne (dotyczy to np. takich elementów, jak: com, $p l)^{48}$.

Warto nadmienić, że istnienie poczty elektronicznej wzbogaciło język nie tylko młodego pokolenia o takie słowa, jak: dżimejl (gmail), onet, interia itp., które przez użytkowników języka są identyfikowane jako elementy adresów elektronicznych. Również słowo matpa zyskało nowe znaczenie;

- korzystania z Internetu, jak: internetowy (sklep, adres, itp.), internauta, net, Sieć, e-łacze;

- korzystania z Internetu łączącego się z komunikacją przez Internet, np. serfować, użytkowania poczty elektronicznej - majlować (czasownik pochodzący od słowa e-mail, który otrzymał polską formę: majl). W przestrzeni Internetu można ponadto do kogoś zamajlować, odmajlować, wysłać meilik. Do tej grupy słów należy też zaliczyć: spam, spamować, blog, blogowy, bloger, blogowicz, video blog $(v \log )^{49}$;

- funkcjonowania w wirtualnej grupie, np. serwis społecznościowy, forum (liczba mnoga: fora) i pochodne tego wyrazu: forumowicz, forumowy ${ }^{50}$, facebook,

48 J. Grzenia, Co język polski zawdzięcza Internetowi? [w:] Oblicza polszczyzny, s. 299.

49 Oddzielny aspekt stanowi język, którym posługują się młodzi użytkownicy vlogów; na ten temat więcej: K. Kuszak, Vlog (młodzieżowy) jako teatr jednego aktora - aspekt komunikacji werbalnej, [w:] Młodzież w dobie przemian społeczno-kulturowych, red. K. Segiet, Poznań 2015, s. 79-91.

50 Tamże, s. 300-302. 
twetter, instagram, (logować się), zalogować się np. do Facebooka, lajki, dodać do grupy;

- slangu internetowego, który ma swoje źródło w języku angielskim i polega na tworzeniu akronimów wyrażeń pochodzących z tego języka najczęściej w formie pisemnej, np. IMO (in my opinion) - moim zdaniem, BTW (by the way) - przy okazji, THX (thanks) - dziękuje itp.

\section{Przestrzeń języka literatury}

Zofia Adamczykowa zauważa, że literatura dla dzieci ma charakter oralny,

co kształtuje sam tekst, jak też modeluje sytuację odbioru. Dziecko z reguły do siódmego roku życia nie potrafi czytać, choć chętnie sięga po książkę, z zainteresowaniem ogląda ilustracje, a nawet symuluje czytanie. Z reguły jednak aż do dziewiątego (dziesiątego) roku życia nie osiąga sprawności w zakresie techniki czytania na takim poziomie, aby samodzielna lektura mogła mu dostarczyć pełnych satysfakcji czytelniczych. Niezbędny jest więc pośrednik. Dziecko-odbiorca dość długo słucha tekstu literackiego, podejmuje z nim grę, oddaje licznym transformacjom i przekładom intersemiotycznym ${ }^{51}$.

Tym pośrednikiem jest rodzic lub inny członek kręgu rodzinnego, nauczyciel (przedszkolny, szkolny), bibliotekarz. Warto też dodać za wspomnianą autorką, iż komunikat w książce zorientowany jest na adresata w określonym wieku, liczy się zatem z jego możliwościami percepcyjnymi i potrzebami rozwojowymi, które zmieniają się ${ }^{52}$. Jest więc bliski dziecku zwłaszcza w warstwie leksykalnej. Dzięki obecności w literaturze dla najmłodszych celowo użytych środków językowych, sprzyja bogaceniu zasobu słownikowego dziecka i rozwijaniu jego kompetencji językowych ${ }^{53}$. Dziecko poznaje:

- Słowa odnoszące się do książek, literatury i czytelnictwa, np. książka, lektura, autor, poeta, powieść, wiersz, poezja, komiks, opowiadanie, historia, bohater, ilustracje, ilustrator, rym, metafora, uosobienie, tytut, zwrotka, zakończenie, spis treści, okładka, ilustracja, ilustrator, wydawnictwo itp. ${ }^{54}$

51 Z. Adamczykowa, Literatura dziecięca. Funkcje - kategorie - gatunki, Warszawa 2004, s. 27-28.

52 Tamże, s. 29.

$53 \mathrm{~W}$ tej części artykułu zostaną przytoczone wybrane przykłady pochodzące z literatury dla dzieci.

54 Słownictwo $\mathrm{z}$ tego zakresu dziecko opanowuje $\mathrm{w}$ procesie edukacji przedszkolnej i szkolnej oraz podczas kontaktów z literaturą na terenie domu rodzinnego. 
- Neologizmy, np. Trablaski55, Pytalski56, Pimpifluszki57, Katużyści58, Rupaki59, zamiaukany60, Skrzydlatek61, Mysikiszki, szczurara, myszara, myszlety, szczurlety62, patataj63, nibywszystko, wspinak, fruwadto, dębołki, wrzosowędrowisko, jodłoobłoki, drzewióry, brzozając, niebieścioro, leśnopolski, nibylas ${ }^{64}$.

- Przysłowia i związki frazeologiczne, np. wybiera sie jak sójka za morze65, nie pamięta wót, jak cielęciem był66, w Szczebrzeszynie chrząszcz brzmi w trzcinie ${ }^{67}$, kurcze blade68, jak wót do karety69, masz babo placek70, kapany w goracej wodzie ${ }^{71}$, niebieski ptak, ranny ptaszek, chodzi spać z kurami, pisze jak kura pazurem, dumny $z$ siebie jest jak paw, jak szara gęś się rządzi, o jajku mądrzejszym od kury, ptaszek we własne sidta wpadt72, po rozum do głowy, petne animuszu, puszczam mimo uszu, obmawia nas poza plecami, to mi jest na ręke, pilnuj swego nosa, patrze przez palce, język mnie świerzbi, nie w ciemię bity ${ }^{73}$, ni to ni sio ${ }^{74}$.

- Komizm słowny, zabawa słowem, np.: "a na obiad zamiast klopsa, spożyt - zły jak mops - rolmopsa75", "może pan się o mnie oprze, pan tak więdnie, panie koprze"76, "był koń, co grat na końtrabasie, najlepiej z koni w swojej klasie i moge dać Wam na to stowo, że końcertować końcertowo"77, w stońcu jest stoń, a w końcu jest koñ ${ }^{78}$.

55 J. Tuwim, Stoń Trąbalski, Warszawa 2015, s. 3-10.

56 J. Brzechwa, Pytalski, [w:] Jan Brzechwa, Sto bajek, Warszawa 1982, s. 115.

${ }^{57}$ L.J. Kern, Stonóżka z Pimpifluszek, [w:] Ludwik Jerzy Kern dzieciom, Warszawa 2012, s. 20.

${ }^{58}$ D. Wawiłow, Kałużyści, [w:] Danuta Wawiłow dzieciom, Warszawa 2013, s. 9.

${ }^{59}$ D. Wawiłow, O Rupakach, [w:] tamże, s. 10-12.

${ }^{60}$ D. Wawiłow, Jesienia, [w:] tamże, s. 22.

${ }^{61}$ J. Papuzińska, Skrzydlatek, [w:] J. Papuzińska, Skrzydlatek $i$ inne opowiadania, Warszawa 1999, s. 5-21.

${ }^{62}$ W. Chotomska, Mysia mowa, [w:] W. Chotomska, Tere-Fere, s. 8.

63 W. Chotomska, W kraju Patataju, Warszawa 2014, s. 2-3.

${ }^{64}$ J. Kulmowa, Nibywszystko, Poznań 2013.

${ }^{65}$ J. Brzechwa, Sójka, [w:] Jan Brzechwa dzieciom, s. 216.

${ }^{66}$ J. Kulmowa, Wót, [w:] J. Kulmowa, Kolory, Warszawa 2014, s. 47.

${ }^{67}$ J. Brzechwa, Chrzaszcz, [w:] Jan Brzechwa dzieciom, s. 222.

${ }^{68}$ W. Chotomska, Kurczę blade, [w:] W. Chotomska, Tere-Fere, s. 94.

${ }^{69}$ W. Chotomska, Wót, [w:] W. Chotomska, Podróże na piórze, Łódź 2012, s. 26.

70 W. Chotomska, Placek, [w:] tamże, s. 22-23.

${ }^{71}$ W. Chotomska, Makaron, [w:] tamże, s. 12-15.

72 A. Frączek, Niebieski ptak, [w:] Agnieszka Frączek, Co ja plotę? Warszawa 2005, s. 19-22.

${ }^{73}$ J. Brzechwa, Po rozum do głowy, [w:] Jan Brzechwa, Sto bajek, s. 164-165.

${ }_{74}$ J. Kulmowa, Ni to ni sio, [w:] J. Kulmowa, Nibywszystko, s. 10.

75 J. Brzechwa, Mops, [w:] Jan Brzechwa, Sto bajek, s. 71.

76 J. Brzechwa, Na straganie, [w:] tamże, s. 91.

77 W. Chotomska, Koń z kontrabasem, [w:] W. Chotomska, W kraju Patataju, s. 20.

${ }^{78}$ J. Ratajczak, Stoń i Koń, [w:] Józef Ratajczak, Wiersze dla dzieci, Wrocław 2000, s. 16. 
- Rzadkie słowa, np. ancymon ${ }^{79}$, androny ${ }^{80}$, animusz ${ }^{81}$, banialuki, fiksumdyrdum, hocki-klocki, widzimisię, dyrdymałki, łapu-capu, zagwozdka, ścichapęk, obibok, fanaberie, drapak, bambuko, kretes, fidrygatki, wygibasy, kołomyja, pstro, smykatka, świszczypata, pędziwiatr, kituś-bajduś na opak, pantatyk ${ }^{82}$.

- Onomatopeje, np. „pada, pada deszcz, chlupu, chlupu, chlup! Idzie dziadziom mrok, tupu, tupu, tup!"83, "po tym ciemnym boru kukułeczka kuka, z ranka do wieczora gniazdka sobie szuka, kuku! kuku! Gniazdka sobie szuka”84, "buch - jak goraco! Uch - jak goraco! Puff - jak goraco! Uff - jak goraco!"85, "halo! O, halo, lo, lo, lo!, Tu tu tu tu tu, Radii, radijo, dijo, ijo, ojo, Pio, pio, pjo, lo, lo, lo, lo, Plo, plo, plo, plo, plo, halo! (...) Ćwir, ćwir, świrk! Świr, świr, ćwirk!"86.

\section{Podsumowanie}

Dzięki funkcjonowaniu dziecka w różnych przestrzeniach języka ojczystego, kształtuje się jego język osobniczy (idiolekt), czyli sposób mówienia właściwy danemu człowiekowi. Język osobniczy związany jest z pochodzeniem jednostki (cechy regionalne), wykształceniem (stopień opanowania norm językowych, stylistycznych), zawodem, tradycjami środowiskowymi (cechy języka środowiskowego), upodobaniami stylistycznymi (np. wpływ lektury) ${ }^{87}$ itp. Podstawy języka osobniczego kształtują się w dzieciństwie, dzięki możliwości udziału dziecka w różnych kontaktach społecznych i różnorodnych sytuacjach użycia języka. Doświadczenia zdobyte w różnych miejscach i sytuacjach komunikacyjnych wzbogacają język osobniczy, co przedstawiono $\mathrm{w}$ tabeli 1 . W zestawieniu tym zwrócono uwagę na miejsca, sytuacje, różnorodność ról pełnionych przez dziecko $w$ przestrzeniach języka ojczystego i wielość słów, zwrotów, fraz, które w każdej z tych przestrzeni poznaje i ma okazję przyswoić.

${ }^{79}$ J. Brzechwa, Szelmostwa lisa Witalisa, [w:] Jan Brzechwa dzieciom, s. 94.

80 J. Brzechwa, Androny, [w:] Jan Brzechwa, Sto bajek, s. 109.

81 J. Brzechwa, Po rozum do głowy, [w:] tamże, s. 164.

82 A. Frączek, Banialuki do zabawy i nauki, Łódź 2011.

83 E. Szelburg-Zarębina, Dziadzio mrok, [w:] E. Szelburg-Zarębina, Idzie niebo ciemna noca, Wrocław 2012, s. 32.

${ }^{84}$ M. Konopnicka, Kukułeczka, [w:] Konopnicka dla najmłodszych, Poznań 1998, s. 42.

85 J. Tuwim Lokomotywa, [w:] J. Tuwim, Lokomotywa, Warszawa 2015, s. 6.

$86 \mathrm{~J}$. Tuwim, Ptasie radio, [w:] tamże, s. 42.

${ }^{87}$ J. Podracki (red.), Szkolny stownik nauki o jezzyku, Warszawa 1998, s. 94-95. 
Tabela 1

Przestrzenie doświadczeń językowych dziecka - podsumowanie

\begin{tabular}{|c|c|c|c|}
\hline $\begin{array}{c}\text { Przestrzeń } \\
\text { języka }\end{array}$ & Miejsca i sytuacje & $\begin{array}{c}\text { Role pełnione przez } \\
\text { dziecko }\end{array}$ & $\begin{array}{l}\text { Charakterystyczne } \\
\text { dla przestrzeni } \\
\text { słowa, nazwy, } \\
\text { środki językowe }\end{array}$ \\
\hline $\begin{array}{l}\text { Język } \\
\text { familijny }\end{array}$ & $\begin{array}{l}\text { dom rodzinny, do- } \\
\text { my/mieszkania } \\
\text { członków dalszej } \\
\text { rodziny, spotkania } \\
\text { z dalszą rodziną }\end{array}$ & $\begin{array}{l}\text { członek rodziny, } \\
\text { dziecko, rodzeń- } \\
\text { stwo, } \\
\text { wnuk/wnuczka, } \\
\text { kuzyn/kuzynka itp. }\end{array}$ & $\begin{array}{l}\text { nazwy i określenia } \\
\text { miejsca i przestrzeni, } \\
\text { nazwy i określenia } \\
\text { domu, formy adresa- } \\
\text { tywne i epitety, } \\
\text { zdrobnienia, formy } \\
\text { pieszczotliwe, formy } \\
\text { odzwierciedlające } \\
\text { relacje między człon- } \\
\text { kami rodziny itp. }\end{array}$ \\
\hline $\begin{array}{l}\text { Język } \\
\text { (przed) } \\
\text { szkolny }\end{array}$ & $\begin{array}{l}\text { przedszkole, szkoła - } \\
\text { lekcje, szkolne, ofi- } \\
\text { cjalne relacje z na- } \\
\text { uczycielami i rówie- } \\
\text { śnikami }\end{array}$ & przedszkolak, uczeń & $\begin{array}{l}\text { słowa określające } \\
\text { rutynowe czynności } \\
\text { dnia szkolnego, } \\
\text { grzeczność językowa, } \\
\text { komunikaty dyrek- } \\
\text { tywne i sterujące, } \\
\text { słownictwo specjali- } \\
\text { styczne itp. }\end{array}$ \\
\hline $\begin{array}{l}\text { Język grupy } \\
\text { rówieśniczej }\end{array}$ & $\begin{array}{l}\text { szkoła - relacje nie- } \\
\text { oficjalne z rówieśni- } \\
\text { kami, przerwy mię- } \\
\text { dzylekcyjne, } \\
\text { spotkania pozasz- } \\
\text { kolne z rówieśnikami }\end{array}$ & kolega/koleżanka & $\begin{array}{l}\text { słowa-wytrychy, } \\
\text { słowa w formie skró- } \\
\text { conej, słowa pocho- } \\
\text { dzące z języka an- } \\
\text { gielskiego, wyzwiska } \\
\text { i przezwiska, wulga- } \\
\text { ryzmy, określenia } \\
\text { obraźliwe itp. }\end{array}$ \\
\hline $\begin{array}{l}\text { Język } \\
\text { reklamy }\end{array}$ & $\begin{array}{l}\text { reklamy w domu, } \\
\text { szkole, przestrzeni } \\
\text { publicznej, np. } \\
\text { w sklepie, na billbo- } \\
\text { ardzie, na ulotce, } \\
\text { w gazecie itp. }\end{array}$ & $\begin{array}{l}\text { odbiorca, konsu- } \\
\text { ment }\end{array}$ & $\begin{array}{l}\text { słowa do rymu, sło- } \\
\text { wa przekształcone } \\
\text { i zmodyfikowane, } \\
\text { słownictwo magicz- } \\
\text { ne, modne wyrazy, } \\
\text { słowa pochodzące } \\
\text { z języka angielskiego, } \\
\text { neologizmy, związki } \\
\text { frazeologiczne itp. }\end{array}$ \\
\hline $\begin{array}{l}\text { Język } \\
\text { Internetu }\end{array}$ & $\begin{array}{l}\text { Internet, sytuacje } \\
\text { korzystania z Inter- } \\
\text { netu, ,spotkania” z } \\
\text { rówieśnikami }\end{array}$ & $\begin{array}{l}\text { odbiorca, nadawca } \\
\text { komunikatów, } \\
\text { współuczestnik } \\
\text { komunikacji za } \\
\text { pośrednictwem } \\
\text { Internetu, } \\
\end{array}$ & $\begin{array}{l}\text { nazwy adresów elek- } \\
\text { tronicznych, słowa } \\
\text { związane z Interne- } \\
\text { tem i komunikacją } \\
\text { przez Internet, slang } \\
\text { internetowy itp. }\end{array}$ \\
\hline
\end{tabular}




\begin{tabular}{|l|l|l|l|}
\hline $\begin{array}{c}\text { Przestrzeń } \\
\text { języka }\end{array}$ & \multicolumn{1}{|c|}{ Miejsca i sytuacje } & $\begin{array}{c}\text { Role pełnione przez } \\
\text { dziecko }\end{array}$ & $\begin{array}{c}\text { Charakterystyczne } \\
\text { dla przestrzeni } \\
\text { słowa, nazwy, } \\
\text { środki językowe }\end{array}$ \\
\hline $\begin{array}{l}\text { Język } \\
\text { literatury }\end{array}$ & $\begin{array}{l}\text { dom rodzinny, } \\
\text { przedszkole, szkoła, } \\
\text { biblioteka }\end{array}$ & $\begin{array}{l}\text { czytelnik, słuchacz, } \\
\text { uczestnik kultury }\end{array}$ & $\begin{array}{l}\text { słowa odnoszące się } \\
\text { do literatury i ksią- } \\
\text { żek, neologizmy, } \\
\text { przysłowia i związki } \\
\text { frazeologiczne, słowa } \\
\text { wywołujące efekt } \\
\text { komiczny, rzadkie } \\
\text { słowa, onomatopeje } \\
\text { itp. }\end{array}$ \\
\hline
\end{tabular}

Wymienione tu przestrzenie językowego funkcjonowania dziecka można traktować jako miejsca, w których wzbogaca ono zasób słownikowy. Dla nauczyciela wiedza na temat specyfiki języka w wymienionych przestrzeniach może być inspiracją do pracy z dziećmi. Może on odwoływać się do słów używanych w różnych przestrzeniach w relacjach mniej lub bardziej oficjalnych (np. Jak byś podziękowat/podziękowata mamie? Jak byś wyrazit wdzięczność nauczycielowi? Jak można podziękować za coś koledze/koleżance?). Może zachęcić do refleksji nad słowami pozwalającymi wyrazić podobne znaczenia $\mathrm{w}$ różnych sytuacjach komunikacyjnych (np. powiesz: przepraszam, sorry, przykro mi, nie chciałem itp.). Może też inspirować do wyrażenia podobnych treści za pomocą innych słów (np. Powiedz to inaczej. Wyraź to innymi słowami).

\section{BIBLIOGRAFIA}

Adamczykowa Z., Literatura dziecięca. Funkcje-kategorie-gatunki, Wyższa Szkoła Pedagogiczna Towarzystwa Wiedzy Powszechnej w Warszawie, Warszawa 2004.

Bralczyk J., Jezzyk na sprzedaż, czyli o tym, jak język stuży reklamie i jak reklama używa języka, Gdańskie Wydawnictwo Psychologiczne, Gdańsk 2004.

Brzechwa J., Sto bajek, Czytelnik, Warszawa 1982.

Brzechwa J., Jan Brzechwa dzieciom, Nasza Księgarnia, Warszawa 2011.

Baylon Ch., Mignot X., Komunikacja, Wydawnictwo Flair, Kraków 2008.

Chotomska W. Podróże na piórze, Wydawnictwo Literatura, Łódź 2012.

Chotomska W., Tere-Fere, Muza SA, Warszawa 2014.

Chotomska W., W kraju Patataju, Muza SA, Warszawa 2014.

Czelakowska D., Metodyka edukacji polonistycznej dzieci w wieku wczesnoszkolnym, Oficyna Wydawnicza Impuls, Kraków 2014.

Czeszlewski M., Słownik polszczyzny potocznej, Wydawnictwo Naukowe PWN, Warszawa 2008. 
Dróżdż-Łuszczyk K., O nowej formie finisaż w systemie leksykalnym polszczyzny, [w:] Język i logopedia, red. Z. Zaron, J. Porayski-Pomsta, Wydawnictwo Uniwersytetu Warszawskiego, Warszawa 2013.

Dysarz Z., Mowa dziecka a więzi uczuciowe w rodzinie, Akademia Bydgoska, Bydgoszcz 2003.

Frączek A., Co ja plotę? Wydawnictwo Nowy Świat, Warszawa 2005.

Frączek A., Banialuki do zabawy i nauki, Wydawnictwo Literatura, Łódź 2011.

Grzenia J., Co język polski zawdzięcza Internetowi? [w:] Oblicza polszczyzny, red. A. Markowski, R. Pawelec, Narodowe Centrum Kultury, Warszawa 2012.

Handke K., Socjologia jezzyka, PWN, Warszawa 2009.

Kern L.J., Stonóżka z Pimpifluszek, [w:] Ludwik Jerzy Kern dzieciom, Nasza Księgarnia, Warszawa 2012.

Konopnicka M., Konopnicka dla najmłodszych, Podsiedlik, Raniowski i Spółka, Poznań 1998.

Kulmowa J. Nibywszystko, G\&P Oficyna Wydawnicza, Poznań 2013.

Kulmowa J., Kolory, MUZA SA, Warszawa 2014.

Kuszak K., Kompetencje językowe uczniów klas młodszych szkoły podstawowej, [w:] Dziecko w szkolnej rzeczywistości. Założony a rzeczywisty obraz edukacji elementarnej, red. H. Sowińska, Wydawnictwo Naukowe UAM, Poznań 2011.

Kuszak K., Kompetencje komunikacyjne dzieci w okresie późnego dzieciństwa w aspekcie rozwojowym, Wydawnictwo Naukowe UAM, Poznań 2011.

Kuszak K., Edukacja językowa jako element edukacji kulturowej uczniów [w:] Kultura - Sztuka - Edukacja, t. I, red. B. Kurowska, K. Łapot-Dzierwa, Uniwersytet Pedagogiczny, Kraków 2015.

Kuszak K., Stownictwo specjalistyczne uczniów w młodszym wieku szkolnym. Zainteresowania i doświadczenia utrwalone w języku, Studia Edukacyjne, 2015, 36.

Kuszak K., Vlog (mtodzieżowy) jako teatr jednego aktora - aspekt komunikacji werbalnej, [w:] Młodzież $w$ dobie przemian społeczno-kulturowych, red. K. Segiet, Wydawnictwo Naukowe UAM, Poznań 2015.

Kuszak K., Werbalne kompetencje w społeczeństwie wiedzy, [w:] Kompetencje kluczowe dzieci i młodzieży. Praktyka edukacyjna, red. J. Uszyńska-Jarmoc, K. Nadachewicz, Wydawnictwo Akademickie Żak, Warszawa 2015.

Lizak J., Jezyk reklam dla dzieci, Wydawnictwo Uniwersytetu Rzeszowskiego, Rzeszów 2006.

Milewski S., Mowa dorostych kierowana do dzieci, Harmonia Universitas, Gdańsk 2011.

Miodek J., Polszczyzna różnych pokoleń, [w:] Oblicza polszczyzny, red. A. Markowski, R. Pawelec, Narodowe Centrum Kultury, Warszawa 2012.

Nęcki Z., Komunikacja międzyludzka, Antykwa, Kraków 2000.

Nowicka M., Socjalizacja na lekcjach w klasach poczatkowych. Praktyki - przestrzenie - konceptualizacje, Wydawnictwo Adam Marszałek, Torun 2010.

Nowicka M., Przestrzeń fizyczna klasy szkolnej jako środowisko socjalizacji dziecka, [w:] Problemy wczesnej edukacji. Problemy, dyskursy, otwarcia, red. D. Klus-Stańska, D. Bronk, A. Malenda, Wydawnictwo Akademickie Żak, Warszawa 2011.

Ollivier B., Nauki o komunikacji, Oficyna Naukowa, Warszawa 2010.

Papuzińska J., Skrzydlatek i inne opowiadania, Literatura, Warszawa 1999.

Podracki J. (red.), Szkolny stownik nauki o języku, Medium, Warszawa 1998.

Ratajczak J., Wiersze dla dzieci, Siedmioróg, Wrocław 2000.

De Saussure F., Szkice z językoznawstwa ogólnego, Dialog, Warszawa 2002. 
Sowa J. Determinanty rozwoju stownika dzieci [w:] Kształcenie języka dziecka w młodszym wieku szkolnym, red. J. Kida, Wyższa Szkoła Pedagogiczna, Rzeszów 1997.

Spychalska M., Hołota M., Stownik sloganów reklamowych, PWN, Warszawa 2009.

Szelburg-Zarębina E., Idzie niebo ciemna noca, Siedmioróg, Wrocław 2012.

Wawiłow D., Danuta Wawitow dzieciom, Nasza Księgarnia, Warszawa 2013.

Tuwim J., Lokomotywa, Muza SA, Warszawa 2015.

Tuwim J., Stoń Trąalski, Muza SA, Warszawa 2015.

Zgółkowa H., Świat w dziecięcych stowach, Wydawnictwo Poznańskie, Poznań 1990.

Zgółkowa H., Gwara uczniowska (szkolna) w poszukiwaniu inspiracji, [w:] Oblicza polszczyzny, red. A. Markowski, R. Pawelec, Narodowe Centrum Kultury, Warszawa 2012. 